\title{
掃引作業における局所的経路再計画による 末知障害物回避
}

\author{
倉 林 大 輔*1 古 賀 信 吾*2 新 井 民 夫*3 太田 順*3

\section{Local Path Replanning for Unforeseen Obstacle Avoidance by Autonomous Sweeping Robots}

\author{
Daisuke Kurabayashi*1, Shingo Koga ${ }^{* 2}$, Tamio Arai ${ }^{* 3}$ and Jun Ota ${ }^{* 3}$
}

\begin{abstract}
In this paper, we propose a planning algorithm for sweeping tasks in environments with unforeseen obstacles. Sweeping means a motion that a robot covers a 2-dimensional area. When a mobile robot finds an unforeseen obstacle, it has to not only avoid collision but also sweep the whole area including where the obstacle is located. In the proposed algorithm, a robot determines local area where sweeping path should be arranged based on it's limited sensing ability. The algorithm avoids heavy calculation cost by limiting the planning area. A robot minimizes length of path when it connects path inside and outside the local area. An autonomous mobile robot can omit running time by the algorithm. We verify the efficiency of the algorithm and discuss the trade-off between running time and sensing/calculation time by simulations and experiments.
\end{abstract}

Key Words: Sweeping, Local Path Replanning, Unforeseen Obstacle Avoidance

1. 序論

工場内での生産活動へのロボット適用が進んだ今日，より一 般的な作業へのロボット適用が期待されている．とりわけ原子 力施設などの定常的な点検, 建築作業における床面加工，清掃 作業などの作業のロボット化が強く求められている。これらの 作業は「掃引作業」と呼ばれ，作業対象となる二次元の面領域 を覆う動作によって特徵づけられる（Fig. 1).

掃引作業に対する動作手法は，大きく反射行動型と計画行動 型に分けられる，反射行動型は，個々のロボットが地図を持た ず，その周辺に限定された環境をセンサにより認識し，それを 直接動作に反映させる手法である [1] [3]. しかし反射行動型 ロボットでは，地図を持たないため有限時間内に作業対象領域 の掃引を完了する保証がない，作業能力が環境の形状に大きく 左右される [4] といった問題点がある. また, 複数台のロボット による掃引作業への拡張を行う場合，作業量の適切な分配を決 定することが困難であるため， ロボット同士の干渉や，掃引の 重複などが発生し，作業効率が悪化する場合がある [5].このた め，実作業に対する掃引作業手法では，作業領域の形状から口

\footnotetext{
原稿受付 1998 年 4 月 7 日

*1 理化学研究所

$* 2$ 日本アイ・ビー・エム

$* 3$ 東京大学工学系研究科

${ }^{* 1}$ Institute of Physical and Chemical Research

$* 2$ IBM Japan

${ }^{* 3}$ The University of Tokyo
}

ボットの動作経路を事前に計画し，作業量の分配を決定する計 画行動型 [6] が現実的である.

しかしながら，実環境での掃引作業において，ロボットが計 画された軌道上をそのまま走行して作業実現を図ると，地図と 実環境との差異が問題となる，その差異は，大きく2 種に分類 される。一つは，地図に記載されていない障害物によって，口 ボットの進路が塞がれる場合である（Fig. $2(\mathrm{~b}))$ 。これは，地 図と実環境の位相構造が異なる差異である。もう一方は, 地

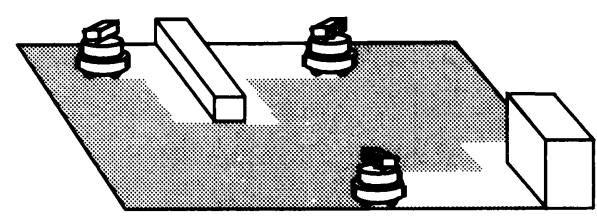

Fig. 1 An example of a sweeping task

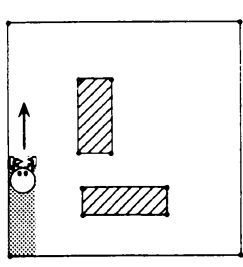

(a) A map

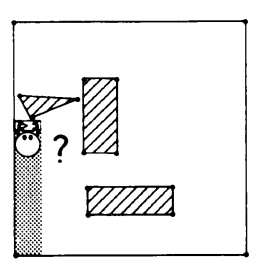

(b) Topological gap

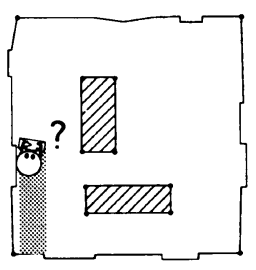

(c) Nontopological gap
Fig. 2 Difference between a map and actual environment 
図のずれや，地図に記載されていない凹凸の存在などである (Fig. $2(\mathrm{c})$ ). これは, 計量的な䛊差である. 実環境での掃引作 業では, 上記 2 種の誤差の考慮が必要となる.

本論文では, Fig. 2(b)のように, 地図に記載されていない 「未知障害物」の存在により, 地図と実環境との間で位相構造 的な差異が生じた状況に対し，オンラインで対処し作業を実現 するという問題を扱う。計量的誤差のみ存在する場合の対処法 については，説明を文献 [7]に蚊り，ここでは扱わない.

対処手法の一つとして，全体の経路計画を繰り返す手法が考 えられる。目標点到達作業においては, 羽田らがリアルタイム に経路計画を繰り返す手法 [8] を提案している。この手法では， すべての領域を常に監視しつづけることが可能であること, 計 画に要する計算が十分早く行われることが必須である。しかし， 一般的には，このような条件が満たされることが期待できない. このため従来の研究では, 未知障害物に遭遇した際，その周讲 を元の計画経路と重なる点まで廻る [9] といったルールが適用さ れるに留まり，結果としてロボットが尣長な動作を行っていた，

このように従来研究では, 計画行動型の最適性を実環境にお いて発揮する手法が欠けていたといえる。

本研究では，ロボットが作業を行いながら，逐次得られた情 報から未知障害物を認識し，局所的に経路再構成を行う手法を 提案する．全体の経路の再計画を避けることにより，計算量の 負荷を軽減し，準最適な掃引動作を可能とする.

以下に，本論文の構成を述べる，第 1 章では，本論文の背景 と目的を述べた。第 2 章において，本研究で扱う問題を定式化 し，提案手法の構成を明らかにする．第 3 章では局所的な経路 再構成による未知障害物回避手法についてその詳細を述べる， 第 4 章において, シミュレーションおよび実験を用いて提案手 法の有効性を検証し，最後に結論を述べる。

\section{2. 概 念 設 計}

\section{1 問題の定式化}

本論文で扱う掃引作業のモデル化，定式化を行う。本論文で は，ロボットおよび掃引作業を次のようにモデル化する。

- 掃引対象領域の形状は, 多角形の障害物の集合 $B_{e n v} に よ$ り表される閉領域とする.

・ロボットは，地図 $B_{m a p}$ を有する.

・ロボットは, 半径 $R$ の円として表される.

・ロボットは, 自己位置の同定が可能である。

・ロボットの経路 $\tau$ は文献 [6] 等の方法を用いてあらかじめ 計算する。それは，曲線分の順列 $\left(t_{1}, t_{2}, \cdots, t_{n}\right)$ により構 成される。

ロボットは，それ自体の大きさがあるため，実際に掃引が実 行可能な領域について考察することが必要となる．掃引対象領 域を構成する障害物 $B_{i}$ は, 次のようにロボットのコンフィグ レーション空間 $C$ へ写像される.これはコンフィグレーション 障害物（以下 C 障害物）と呼ばれる。

$$
C B_{i}=\left\{q \in C \mid A(q) \cap B_{i} \neq \phi\right\}
$$

$A(q)$ は，ロボット $A$ があるコンフィグレーション $q$ にある とき，掃引対象領域においてロボットが占める領域を表す。す
ベての $\mathrm{C}$ 障害物の統合 $\bigcup_{i=1}^{q} C B_{i}$ を $\mathrm{C}$ 障害物領域と呼ぶ. $C$ において C 障害物領域を除いた空間 $C_{\text {free }}$ が，ロボットが動 作可能な自由空間である。ここで，“〉は，集合から要素を除 去する操作を示す.

$$
C_{\text {free }}=C \backslash \bigcup_{i=1}^{q} C B_{i}
$$

ロボットを円形とモデル化したため，ロボットの姿勢は考慮 しない.つまり，ロボットのコンフィグレーション $q$ のうち， 位置成分のみを扱う. $C_{\text {free }}$ に含まれるすべての $q$ に対する $A(q)$ により構成される領域を $W_{\text {sweep }}$ と記述し，掃引可能領 域と呼ぶ。 $W_{\text {sweep }}$ は掃引対象領域内でロボットが掃引可能な 領域を表している.

この条件の下, 経路 $\tau$ が式（3）を満たすとき, 掃引作業が 達成される。ここで, $d(\tau, p)$ は経路 $\tau$ と点 $p$ との距離を表す.

$$
\forall p \in W_{\text {sweep }} \quad d(\tau, p) \leq R
$$

本研究で扱う問題は, 未知障害物 $B_{j+i}$ が現れた際, 式 (3) を満たし，かつ $\left\|\tau_{i}^{\prime}\right\|$ を準最短とする経路 $\tau^{\prime}$ を $\tau$ からリアル タイムで構成することである。

ここで，ロボットの環境計測能力について仮定をおく.

- 実環境 $B_{\text {new }}$ は, $B_{\text {map }}$ に加え未知障害物 $B_{\text {new }}$ を含んで いる.

・ロボットは，自己位置より半径 $L$ の円内に存在する $B_{n e w}$ の要素を認識可能. ただし, $L>R$ とする.

$L=R$ とした場合，ロボットと環境との接触点のみの計測が 行われることとなる。しかし, 接触点が計測される都度計画を 行っていては, 計画回数が膨大となってしまう。本章では, 口 ボットにおいて CCD カメラを用いることを念頭におき，点だ けではなく辺 $E\left(B_{\text {new }}\right)$ の要素の一部が検出された場合につい て，オンラインでの計画を適用する。また， $L>>R$ とした場 合でも，他の障害物に遮られる場合や，障害物の裏側など不可 視な領域が発生するため，本章で提案する局所的な計画手法が 有効に適用されると考えられる，具体的なスケールについては， 4 章において考察する.

ロボットの走行速度は, 作業の実行速度により律速されるも のとし，未知障害物の発見はサンプリングタイム時間内に可能 とする。発見した障害物の形状の計測には，別途に計測時間を 要するものと仮定する。

\section{2 局所的な経路再構成手法の提案}

掃引作業の完了のためには，ロボットの軌跡が式（3）を満 たしていることが必要である、ロボットが作業途上で未知障害 物に遭遇した際，未知障害物を含めた領域形状に対して，条件 式を満たすように経路を修正することが必要となる。この際， ロボットは以下の 3 種の時間的コストを費やす必要がある.

- 計算時間 (計算量)

- 計測時間

- 動作時間 (経路長)

未知障害物の形状を完全に調べ，地図を更新しすべての経路を 生成し直せば, 掃引経路長は最も短くなり，動作時間が縮小さ れることが期待できる。しかし，掃引経路生成に要する計算量 


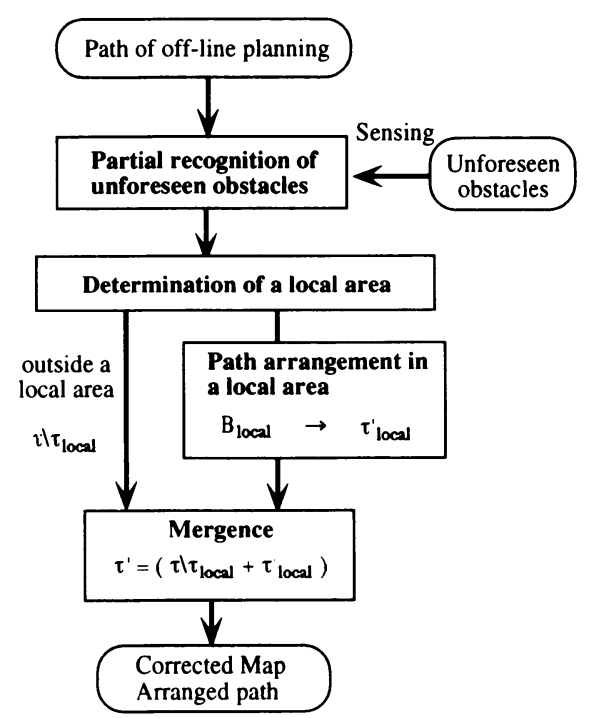

Fig. 3 Outline of the local path replanning

が大きいこと, また, ロボットの限られたセンサ能力での未知 障害物計測に要する時間が大きいことが問題となる。

本研究では, 未知障害物の段階的認識と局所的な経路再構成 による未知障害物への対処手法を提案する．全体を掃引する経 路は事前に与えられているものとする。ここでは,

（1）未知障害物の一部を認知することにより，全体の経路の なかから修正すべき局所領域を限定し，その局所領域内の掃引 経路を生成する。

（2）局所領域内の経路と, 変更を行わなかった部分の経路を 最短でたどる新たな経路を生成し，掃引作業を遂行する。これ らを再帰的に繰り返すことにより，経路計画および障害物認知 に要する時間を縮減した, 高効率の掃引作業計画手法を構筑 する.

この概念に基づいて, Fig. 3 に示すようにオンラインでの計 画手法を構成する. 詳細については次章で述べるものとし, こ こではその概略を示す。

ロボットは未知障害物 $B_{n e w}$ の要素の一部を発見すると, 再 計画を行うことが必要な領域 $B_{l o c a l}$, 再計画が必要となる経 路の曲線分集合 $\tau_{\text {local }}$ を決定する. 局所領域内においてのみ, $B_{\text {local }}$ と計測された $B_{n e w}$ の要素から $\tau_{\text {local }}^{\prime}$ を計画する. 局所 領域に含まれない部分 $\tau \backslash \tau_{\text {local }}$ については改変を行わない. 最 後に $\tau \backslash \tau_{\text {local }}$ と $\tau_{\text {local }}^{\prime}$ の要素の曲線分を最短でたどる順序を決 定し，修正された掃引経路 $\tau^{\prime}$ を生成する.

この手法においては, 局所領域外の掃引はオフラインでの経 路 $\tau \backslash \tau_{\text {local }}$ により保証されているため, 局所領域内でのみ, 経 路に対する掃引の拘束条件を再度考慮することのみが必要と なる。

\section{3. 局所的な掃引経路再構成手法}

\section{1 局所領域の決定}

未知障害物の存在により，ロボットが計画通り掃引すること ができない経路が一部生じる。ここでは, 未知障害物を回避し

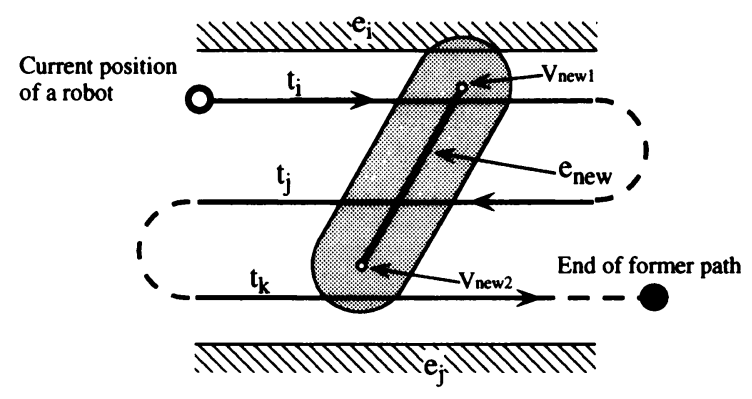

(a) A local area

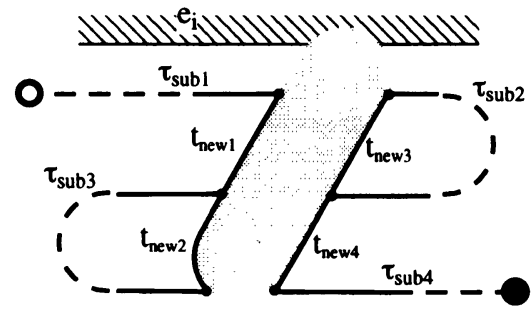

तIIIIIIIIIIIII

(b) Generated curves

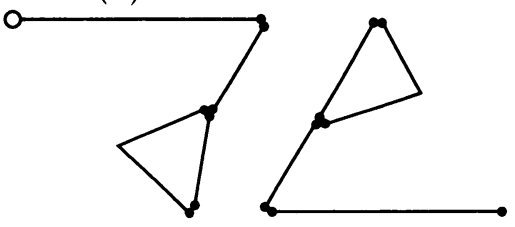

(c) Calculation of minimum length path

Fig. 4 Schematic view of path arrangement

た掃引経路への修正が必要な局所領域を決定する。

経路の局所的な修正を可能とするためには，

・経路 $\tau$ のうち, 修正を必要とする曲線分

・認識した未知障害物に対する掃引経路を生成する際に，干 涉する可能性のある環境地図中の辺, 頂点を求めることが 必要である. すなわち, $\tau$ および $B_{e n v}$ 中の上記要素を限

定することをもって，局所領域の決定とする.

仮定に基づき，ロボットは視野内で発見した未知障害物 $B_{n e w}$ の要素辺 $e_{n e w}, v_{n e w 1}, v_{n e w 2}$ を認識する (Fig. 4(a))。この 障害物に対し構成される $\mathrm{C}$ 障害物の内部（Fig.4 のハッチング された領域）にはロボットが進入できない.

移動ロボットを半径 $R$ の円形と仮定しているので， C 障害 物 $C B_{\text {new }}$ を掃引対象領域に投影した形状は

$$
\text { Projection_C } B_{\text {new }}=\left\{p \mid d\left(p, e_{\text {new }}\right) \leq R\right\}
$$

と表すことができる。ここで $p$ は掃引対象領域中の点を表す. また，投影された $\mathrm{C}$ 障害物の境界線は， $e_{n e w}$ を $e_{n e w}$ と直交 する方向に距離 $R$ だけオフセットした線分と, $v_{\text {new } 1}, v_{\text {new } 2}$ に関する半径 $R$ の半円周により構成することができる.

経路を構成する曲線分のうち，この C 障害物内部を通過する ものが，ロボットが計画通り掃引することのできない経路であ る.この曲線分は，次の条件によって判別する。

$$
\tau_{\text {local }}=\left\{t_{i} \in \tau \mid d\left(t_{i}, e_{\text {new }}\right) \leq R\right\}
$$


地図 $B_{e n v}$ の構成要素である辺のうち, $e_{n e w}$ からの距離が ロボットの直径 $2 R$ 以下であるものは， $e_{n e w}$ に対する掃引経 路を生成する際にロボットとの干渉が発生する。このことから， 局所領域を構成する， $B_{\text {env }}$ 中の辺を，次の条件により判別す る. あわせて，辺に接する頂点についても判別する.

$$
\begin{aligned}
& E\left(B_{\text {local }}\right)=\left\{e_{i} \in E \mid d\left(e_{i}, e_{\text {new }}\right) \leq 2 R\right\} \\
& V\left(B_{\text {local }}\right)=\left\{v_{j} \in V \mid d\left(v_{j}, e_{\text {new }}\right) \leq 2 R\right\}
\end{aligned}
$$

以上によって, $e_{n e w}$ の認識による, 経路修正の局所領域 $\tau_{\text {local }}$, $B_{\text {local }}$ を決定する.

\section{2 局所領域における掃引経路導出}

本節では，前節で構成された局所領域において，経路として 通過が必要な曲線分を生成する。

新たに認知された障害物（の一部）により，ロボットは事前 に計画された経路の一部をたどることができなくなる．逆に， その障害物の周囲をくまなく掃引するために，新たな経路の付 加が必要となる。また，発見された障害物によって，領域の一 部が遮られ，ロボットが進入することができなくなる可能性が ある、ロボットの動作を継続させるためには，これを判定し， 経路から除去することが必要である。本節では，

(1) 局所領域での計画経路の修正

（2）末知障害物に対する掃引経路生成

(3) 進入不可領域に対する経路の除去

について，手順を追って述べる.

\section{2 .1 局所領域での計画経路の修正}

前節で局所領域とされた経路の曲線分は， $e_{n e w}$ による C 障 害物に含まれない部分は掃引作業の達成のために必要な部分で ある。そこで， $\mathrm{C}$ 障害物に含まれる部分を除去し，残された部 分をあらたな曲線分として生成する。

$e_{n e w}$ に対する $\mathrm{C}$ 障害物の境界線は， $e_{n e w}$ を $e_{n e w}$ と直交 する方向に距離 $R$ だけオフセットした二つの線分と, $v_{\text {new } 1}$, $v_{n e w 2}$ に関する半径 $R$ の二つの半円周により構成される，局 所領域に含まれた曲線分 $t_{i} \in \tau_{\text {local }}$ について，これらとの交点 を算出する．交点で曲線分を分割し，C障害物中に含まれる部 分を消去する．残された曲線分を新たに $t_{i 1}, t_{i 2}$ とし， $\tau$ 中で $t_{i}$ と㯰き換える.

これにより，

$$
\tau=\left(t_{1}, \cdots, t_{i}, \cdots, t_{j}, \cdots, \cdots, t_{n_{t}}\right)
$$

であった計画時の経路は,

$$
\begin{gathered}
\tau_{s u b_{1}}=\left(t_{1}, \cdots, t_{i 1}\right) \\
\tau_{s u b_{2}}=\left(t_{i 2}, \cdots, t_{j 1}\right) \\
\vdots \\
\tau_{s u b_{m}}=\left(\cdots t_{n_{t}}\right)
\end{gathered}
$$

の複数の連結成分に分割される（Fig.4 (a)(b)).

\section{2 .2 未知障害物に対する掃引経路生成}

掃引作業を完了させるためには，未知障害物を回避するだけ でなく, 認識された末知障害物 $e_{n e w}$ の周囲に掃引されない領 域が残らぬよう経路を生成することが必要となる。この際，経 路として $e_{n e w}$, の 障害物境界線を用いることが適当であると 考えられる.

経路を生成する際， $e_{\text {new }}$ の C 障害物境界線は，局所領域に おいて輪郭線 $e_{i} \in E\left(B_{\text {local }}\right)$ と干渉する可能性がある。また, $e_{i} \in E\left(B_{\text {local }}\right), v_{j} \in V\left(B_{\text {local }}\right)$ の C 障害物中には, ロボット が進入できない。このため， C 障害物境界線を構成する二つの 線分, 二つの半円周について, $e_{i} \in E\left(B_{\text {local }}\right)$ を距離 $R$ オフ セットして生成される $\mathrm{C}$ 障害物境界線および $v_{j} \in V\left(B_{\text {local }}\right)$ を中心とする半径 $R$ の円となる $\mathrm{C}$ 障害物境界線との交点を算 出する。交点が存在した場合，その交点で $e_{n e w}$ の C 障害物境 界線を分割し, $e_{i} \in E\left(B_{\text {local }}\right), v_{j} \in V\left(B_{\text {local }}\right)$ の $\mathrm{C}$ 障害物中 に含まれる部分を消去する。

最後に，これまでに生成した曲線分との交点を算出する。曲 線分の端点以外で交点が存在する場合，交点で曲線分を分割す る.ここで生成された曲線分が， $e_{n e w}$ に関して掃引を行う経 路となる。これらの曲線分を $t_{n e w 1}, t_{n e w 2}, \cdots$ と称するものと する。

\section{2 .3 進入不可領域に対する経路の除去}

本項で扱う進入不可領域とは， $e_{n e w}$ の存在によってロボッ トが到達することができなくなる領域を意味する（Fig. 5 ). 本 手法では，未知障害物の形状を逐次得られた辺についてのみ認 識しており，障害物の内部・外部の区別を行っていない。その ため，順に箱を閉じるように形状が認識された障害物内に残さ れた経路を除去することが必要となる。

前項において生成された連結成分 $\tau_{s u b_{1}}, \cdots$ および $t_{n e w 1}, \cdots$ において，曲線分上の任意の 1 点を選ぶ。ロボットの現在值か らこの点までを結ぶ，障害物と干涉しない曲線を引くことがで きるか否かにより，ある連結成分が進入不可能領域にあるか否 かを判断することができる，進入不可領域中の経路は，ロボッ トが到達できないため，この時点で除去する。

平面上での 2 地点間を結ぶ経路生成問題は，これまで数多く 議論されている。ここでは, [10]に示されている，可視グラフ による経路生成手法を適用し，障害物と干渉しない曲線が引け るか否かを判定する。

\section{3 経路の統合}

元の計画経路から生成された $\tau_{s u b_{1}}, \cdots$ が局所領域外の掃引 を保証し， $t_{n e w 1}, \cdots に よ り$ 局所領域内の掃引が保証される。こ れらをすべてたどることによって，末知障害物回避を行い，全

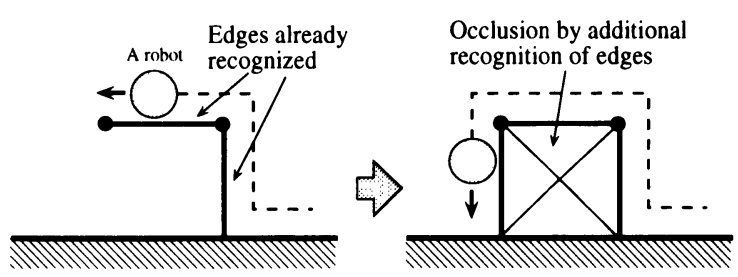

Fig. 5 Detection of inside of an unforeseen obstacle 
域の掃引を実現する経路が生成される。これらの曲線分を最短 で巡ることが，準最適な経路を与える。

前節で生成された曲線分の連結成分 $\tau_{s u b_{1}}, \cdots$ および $t_{\text {new } 1}, \cdots に$ に扔いて, これらの通過順序を決定する際, 各連 結成分の両端点を抽出し, これらの通過経路を決定することで 十分である (Fig. 4 (c))。これは, 生成された連結成分はその すべてを通過することが必要であるため, 経路全体に対する経 路長はこれらを通過するために付与される経路長によってのみ， 長短が決定されるためである。抽出された 2 端点間を結ぶ経路 の算出にあたっては, 可視グラフ $[10]$ を用いて最短路を求める.

このように各連結成分の両端点を抽出することで, 最短経路 決定問題は, 連結成分の順列を決定する組み合わせ最適化問題 となる.この最適化問題はグラフ理論におけるルーラルポスト マン問題 (RPP) [11] に帰着することができる.ルーラルポス トマン問題とは, 巡回セールスマン問題で「都市」に例えられ ていた点を，線分に拡張した問題である。

\section{4. 局所的な掃引経路再構成手法の検証}

本章では，提案手法の実現性と，作業時間短縮に対する有効 性の検証を行う。はじめに, 提案手法の計算量について考察す る、計算量のオーダーを考察した後, 筆者らのロボットシステ ムと照らし合わせ，オーダーを支配するパラメタの大きさを考 察するとともに, 実験を通じて, 未知障害物計測, 局所経路再 計画, 軌跡長から作業時間短縮について具体的に考察する. 次 いで，未知障害物の大きさ，形状を変化させた場合について， 提案手法により軌跡長短縮による作業時間短縮が可能であるこ とを示す.

\section{1 計算時間考察と実験による検証}

提案手法において, 組み合わせ最適化の対象となる, 生成さ れた連結成分と曲線分の数を $n$ とする.ルーラルポストマン問 題では, その計算量は $O\left(2^{n} n^{3}\right)$ である。この最適化計算は $n$ の值の増大に敏感であるといえ, この手法が実行可能かどうか は $n$ の值が十分小さいことにかかっている.

認識された未知障害物の辺 $B_{n e w}$ より生成されるコンフィグ レーション障害物 $C B_{\text {new }}$ と, 経路 $\tau$ が $m$ 箇所で交わった場 合, $\tau$ は $m+1$ 個の $\tau_{\text {sub }}$ に分割される。また, $B_{\text {new }}$ の周囲 を掃引するための曲線分は, 最大 $2 m$ 個生成される。このため, $n$ は $3 m+1$ 個程度の要素を含むことになる。 $m$ の大きさは, 未知障害物の大きさおよびロボットのセンシングエリアの大き さに依存して変化する。未知障害物の大きさが, ロボットのセ ンシングエリアより大きいと仮定した場合， $m$ はセンシング エリア内に存在する $\tau$ の曲線分の数となる.この曲線分が, 口 ボットの掃引単位（直径 $2 R$ ） を並ベた数だけ存在すると, $m$ は最大で $\frac{L}{R}$ 程度となる。この值について, 実機ロボットを基 に考察する。

筆者らが製作した移動ロボットを Fig. 6 (a) に示す。このロ ボットは理化学研究所において開発された全方向移動機構 [13] を有する自律移動ロボットであり, 半径 $R=0.3[\mathrm{~m}]$ の大きさ を持つ、上部には CCD カメラを有し, センシングエリア半径 $L=2.0[\mathrm{~m}]$ において, 筆者らが提案した発光ダイオードのマー カー [14] を観測し，相対位置を計測することが可能である。口

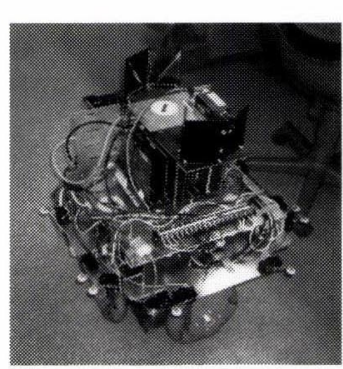

(a) A mobile robot

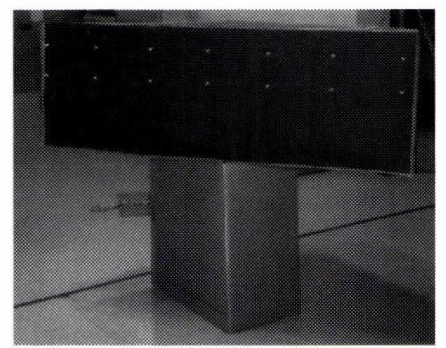

(b) an "unforeseen" obstacle

Fig. 6 Components of the experimental system

ボットに搭載した画像処理システムは能力が低く，一般画像か ら障害物の辺を抽出することが困難であったため, Fig. $6(\mathrm{~b}) に$ 示すように障害物壁面にマーカーを配列しこれを計測するもの とした.CPUはIntel DX4-100 [MHz] を搭載している.

このロボットシステムにおいては， $L$ と $R$ の值より, 最大で $m$ は 6 程度であり, $n$ は 20 未満であると考察される. 実際に は，未知障害物が小さい場合， $n$ はより小さくなる．Fig. 4 (c) の例では, $n=8$ である.

一方，仮に $n=20$ をオーダー表現に当てはめた場合， $2^{20} 20^{3} \simeq 10^{10}$ ，およそ 10 ギガ回オーダーの演算が必要となる. これに対し, Intel DX4-100 [MHz] で 6MFLOPS（1 秒間に 6 メガ回の浮動小数点演算), PentiumII で 50MFLOPS 程度の 演算能力を有する. 提案手法の演算は, 組み合わせ最適化計算 なので, 必ずしも浮動小数点演算は要求されないが, 現実的に は $n=20$ 程度が限界であるといえる。

これらの点から、筆者らのロボットのように，センシングエ リア $2.0[\mathrm{~m}]$, 掃引単位半径 $0.3[\mathrm{~m}]$ の場合は, オーダーの点か らは計算は十分可能であるといえる。しかし, オーダー標記で は現れない計算量や, 再計画に付帯する処理の時間などを考察 し, 提案手法の有効性を検討することが必要となる。ここでは, 実験により，これらについて考察する。

ロボットは, 速度 $0.09[\mathrm{~m} / \mathrm{s}]$, 制御サンプリングタイム $100[\mathrm{~ms}]$ で，モータに装着されたエンコーダの回転量から 自己位置を推定するデッドレコニングにより動作を行う。ロ ボットの CCD カメラは, 視野角が $\pm 20^{\circ}$ しかないため, 未知 障害物を発見すると, 左右に向きをかえて形状を認識する。な お，計測したマーカーが以前に認識したものと同一か否かは， 既知のマーカーとの距離がしきい值以下か否かによって判断す る、実験においては, ロボットの移動誤差, カメラの計測䛊差 を考慮して，しきい值は $0.05[\mathrm{~m}]$ とした。

Fig. 7 (a) に示す掃引領域を用意し，シミュレーションおよ び実機実験双方を行った。Fig. 7 中，斜線でハッチングされた 円がロボットを表す。中央の黒い正方形は, 地図にあらかじめ 記載されている障害物であり，ハッチングされた三角形が未知 障害物である。同一条件のシミュレーションにおけるロボット の動作手順を Fig. 7 (b) (c) に, 実機実験におけるロボットの軌 跡を Fig. 7 (d) に示す.

未知障害物を発見するまでは，ロボットはFig.7 (a) 太実線 に示される経路に浴って動作していく，障害物を発見すると， 


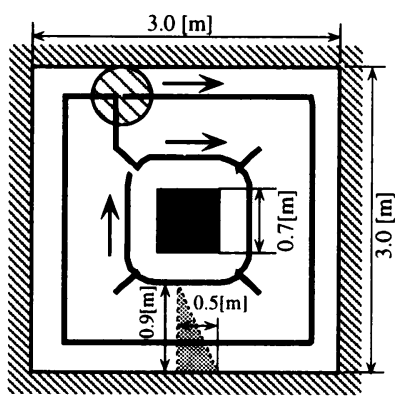

(a) Off-line path

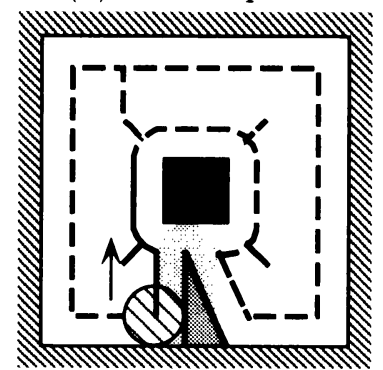

(c) Second replanning

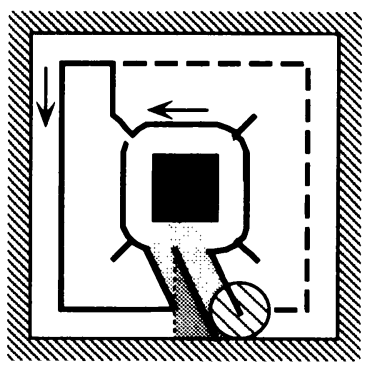

(b) First replanning

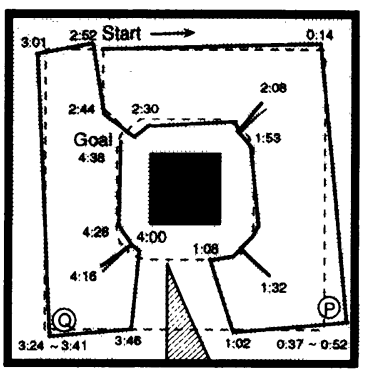

(d) Experimental result
Fig. 7 Procedure of proposed algorithm

視野内の辺のみを認識する。この辺により影響を受ける部分を 局所的に再計画し，全体の経路として再構成する (Fig. 7 (b)). この際，中央の既知障害物の周囲を掃引する部分の経路を，時 計回りから反時計回りに变更している. Fig. 7 (d) では, 最終的 にすべての障害物形状を認識し，かつ掃引作業を完了している.

Fig. 7 (d)において，実線はロボットの軌跡を，破線は事前の 計画経路を表している. 実験結果におけるロボットの軌跡より， シミュレーションと同様に, 未知障害物回避, 掃引作業達成が 実現されている。

ロボットは, Fig. 7 (d) 中の地点 $P, Q$ において, 未知障害物 の 1 辺を認識し, 経路の修正を行っている.この際, 地点 $P$ に は 15 秒間， $Q$ には 17 秒間留まっていた。いずれの場合も, 留 まった時間は計測時間として要したもので, 経路修正アルゴリ ズムの実行はサンプリング時間未満で行われた。提案手法によ るロボットの走行軌跡長は $16.4[\mathrm{~m}]$ であった。

ここで，文献 [9]に見られる，「未知障害物に遭遇したら，一 定方向に元の経路に遭遇するまで旋回する」というルールに よる手法でロボットに未知障害物の回避を行わせた場合との 比較を考察する. 上記手法は, 移動ロボットのオンライン動作 計画時にしばしば用いられるものである。ルールによる場合 でも, 提案手法と同様の事前計画経路を与え, 未知障害物回 避問題のみに着目した。ルールによる場合, Fig. 7(a)の例で は, 未知障害物回避のために大きく回り道をすることとなり, 軌跡長は $22.1[\mathrm{~m}]$ となる。このため, ロボットの走行時間は, $\frac{22.1[\mathrm{~m}]-16.4[\mathrm{~m}]}{0.09[\mathrm{~m} / \mathrm{s}]}=64.5[\mathrm{~s}]$ となり, 提案手法より大きくなる. 提案手法は未知障害物の計測と計画に $32[\mathrm{~s}]$ を要したが，なお 約 $32.5[\mathrm{~s}]$ 早く掃引作業を完了すると評価できる.

この結果から, 本章で構築した未知障害物回避手法が実際の

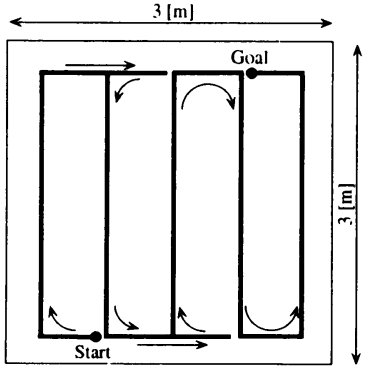

(a) Given sweeping path

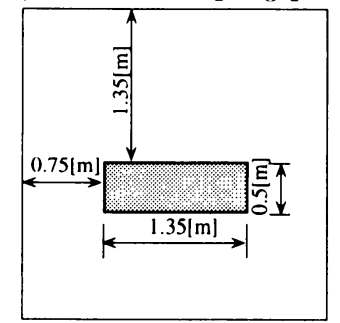

(c) Area 2

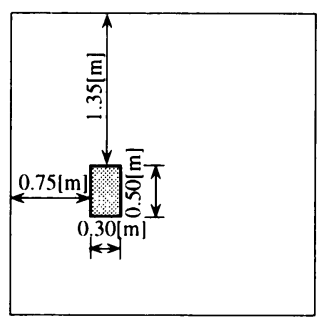

(b) Area 1

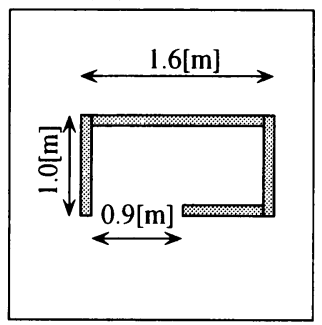

(d) Area 3
Fig. 8 Conditions for simulations

移動ロボットシステムにおいて，再計画に要する時間を考慮し ても, 掃引軌跡長短縮により, 作業時間を短縮できたことが示 された。

なお， 実験でのロボットの動作軌跡は, 計画経路からずれて いる部分が存在し，全体として左回りにずれた形となっている. この䛊差要因としては，ロボットの走行時の位置推定誤差，お よびロボットを初期位置に設置する際の位置誤差が考えられる。 これにより掃引が行われない領域が発生した。しかし，ロボッ 卜はFig. 7 (c) と同様の軌跡を残していることから，本研究で 提案したアルゴリズムの検証には十分な結果であるといえる. この障害物認識誤差およびロボットの走行誤差については, 別 の文献 [7]において示す環境適応手法により対処可能である.

\section{2 シミュレーションによる末知障害物回避軌跡の比較}

ここでは，ロボットの軌跡拉よびその長さについて，共通の オフラインでの掃引経路に対して, 提案手法とルールにより 未知障害物を回避した場合とを比較考察する。オフラインで の掃引経路として, 文献 $[9]$ などに用いられているジクザク状 (direction parallel 型) の経路を与えた場合を取り上げる。用 いたルールは, 文献 [9] やオンライン時の未知障害物回避手法と してしばしば用いられる,「未知障害物に遭遇したら，一定方向 に元の経路に遭遇するまで旋回する」を採用した。シミュレー ションに際し，先のシミュレーションと同様に条件を設定した。

- 領域は $3[\mathrm{~m}] \times 3[\mathrm{~m}]$ の正方形形状.

- Fig. 8 (a) 太線で示される梯子状の経路を計画経路として 与える。

・ロボット半径 $R=0.3[\mathrm{~m}]$, センシングエリア半径 $L=2[\mathrm{~m}]$.

・ロボットの走行速度 $0.09[\mathrm{~m} / \mathrm{s}]$.

Fig. 8 (b) 一 (d) に示すように未知障害物の形状を変えた Area 1〜3を設定し，ロボットの軌跡を比較した. 

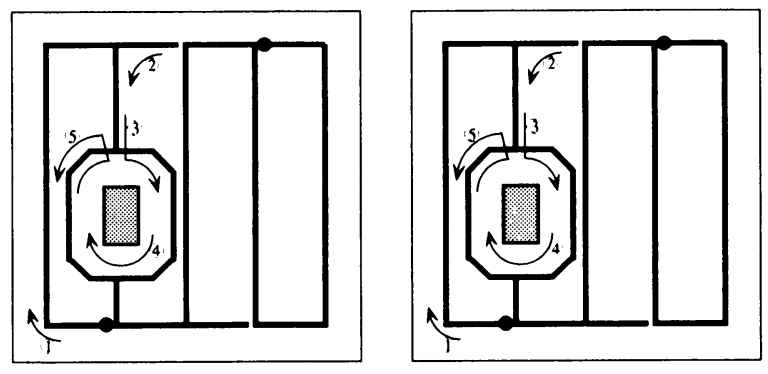

(i) In area 1
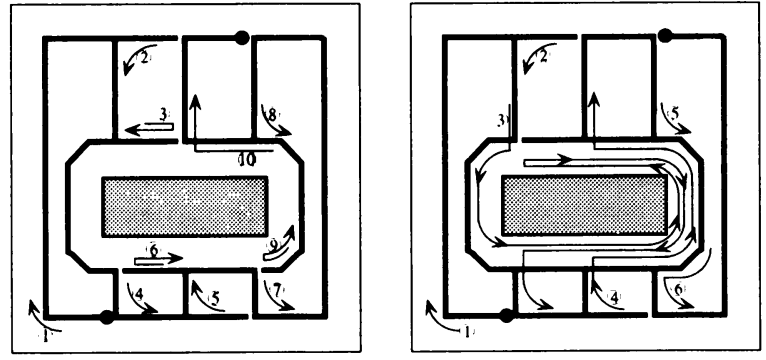

(ii) In area 2
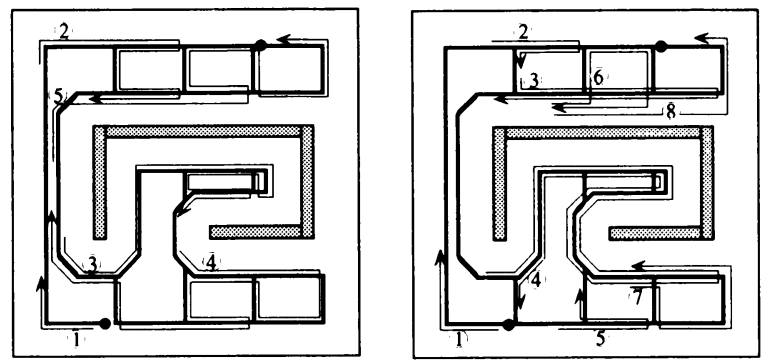

(iii) In area 3

(a) Proposed algorithm

(b) Rule based

Fig. 9 Comparison of sweeping trajectories

シミュレーション結果をFig. 9 に示す。また，掃引完了ま での軌跡の長さの比較を Fig. 10 に示す，図において，左側が 提案手法によるロボットの軌跡, 右側が未知障害物の周囲を単 純に迂回するというルールベースの動作によるロボットの軌跡 を示している. 未知障害物の大きさが最も小さいA Area 1 では, 提案手法とルールによる回避手法は同様の経路を生成している. これは, どちらの手法においても, 結果として未知障害物の周 囲を掃引する経路が追加されたのみで，局所領域外の経路での 通過順序に変化がなかったためである。

これに対し，未知障害物の大きさが大きくなるにつれて，提案 手法の軌跡長がルールによる回避に比べ短くなっている. Area 1 では両者は同一の値となるが, Area 2 では約 $23 \%$, Area 3 では約 $33 \%$ 提案手法の軌跡が短くなっている。これは,ルール による回避では, 計画経路において未知障害物と父差する部分 が增大するにつれ，回避に要する動作において重複して通過す る部分が増大するためと考えられる。

この結果より, Area 1では, 計測および計画時間を費やす分, 提案手法が不利である。一方, Area 2, Area 3ではそれぞれ $\frac{34.08[\mathrm{~m}]-26.27[\mathrm{~m}]}{0.09[\mathrm{~m} / \mathrm{s}]}=86.8[\mathrm{~s}], \frac{48.41[\mathrm{~m}]-32.33[\mathrm{~m}]}{0.09[\mathrm{~m} / \mathrm{s}]}=178.7[\mathrm{~s}]$

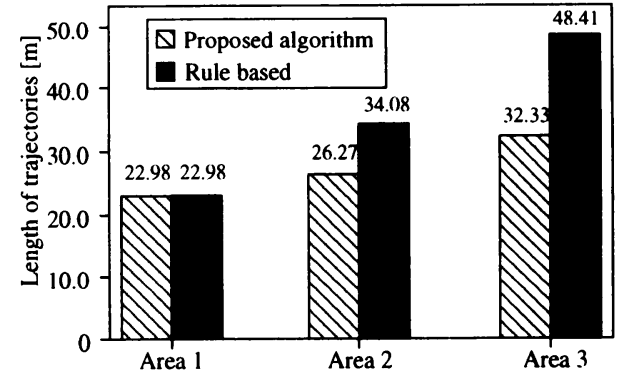

Fig. 10 Comparison of length of sweeping trajectories

動作時間が短縮される．計画および計測時間が先の実験例のよ うにこれら以下であれば，提案手法により作業時間を短縮する ことが可能となる。このことから，計画経路と交差する部分の 多い未知障害物の存在に対してより有効性を発揮することがで きるといえる。

\section{5. 結}

論

本研究では, 移動ロボットの掃引作業において, 実際の作業 中に未知なる障害物を発見した場合に，その未知障害物周辺を 切り出す事によって, 障害物を回避し, かつ掃引作業を最後ま で遂行する手法を提案した。

シミュレーションにより，ロボットが作業の妨げとなる未知 障害物を発見しても, 発見するたびごとに作業経路を高速に改 変できることを確かめた。また，実験により，現実のロボット システムにおいて機能および処理時間の点で有効であることを 確かめた。

謝 辞 本研究を進めるにあたり, 実験装置の構成において, 理化学研究所の遠藤 勲氏, 淺間一氏, 嘉悦早人氏に御協力を いただきました。ここに感謝いたします。

\section{参 考 文 献}

[1] S. Goss and J.L. Deneubourg: "Harvesting By A Group of Robot," in "Towards a Practice of Autonomous Systems," Proc. of the 1st European Conf. on Artificial Life, MIT Press, pp.195-204, 1992.

[2] T. Balch and R.C. Arkin: "Communication in Reactive Multiagent Robotic Systems," Autonomous Robots, 1, pp.27-52, 1994.

[3] E. González, A. Suárez, C., Moreno and A. Artigue: "Complementary Reginos: a Surface Filling Algorithm," Proc. IEEE Int. Conf. on Robotics and Automation, pp.909-914, 1996.

[4] 坂井, 他：“反射行動を利用した自律清掃ロボットの研究”, 第 14 回 日本ロボット学会学術講演会予稿集, pp.313-314, 1996.

[5] R, Beckers, O.E. Holland and J.L. Deneubourg: From Local Action to Global Tasks: Stigmergy and Collective Robotics Artificial Life 4, pp.181-189, 1994.

[6] 倉林, 他：“掃引作業における移動ロボット群の動作計画”, 日本口 ボット学会誌, vol.16, no.2, pp.181-188, 1998.

[7] D. Kurabayashi, et al.: "Real-time Path Adaptation for Sweeping by Autonomous Mobile Robots," Distributed Autonomous Robotic Systems 3, pp.299-308, 1998.

[8] 羽田, 高瀬：“認識と計画の実時間統合に基づくロボットの作業 レベルフィードバック制御”, 日本ロボット学会誌, vol.15, no.2, pp.296-305, 1997

[9] V. Lumelsky, et al., Sensor-Based Terrain Acquisition: A "Seed Spreader" Strategy, Proc. IEEE/RSJ Int. Workshop on Intelli- 
gent Robots and Systems, pp.62-67, 1989.

[10] J.C. Latombe: Robot Motion Planning. Kluwer Academic Publishers, 1991

[11] E.L. Lawler, et al.: The Traveling Salesman Problem. John Wiley \& Sons Ltd., 1985.

[12] D.S. Johnson and C.H. Papadimitriou: "Performance guaran- tees for heuristics," The Traveling Salesman Problem. pp.145$180,1995$.

[13] 淺間, 他：“3 自由度独立駆動型全方向移動ロボットの開発”, 日本ロ ボット学会誌, vol.14, no.2, pp.249-254, 1996.

[14] 新井, 他：“移動ロボットの相互位置・姿勢実時間計測システムの開 発”, 日本ロボット学会誌, vol.12, no.3, pp.472-478, 1994.

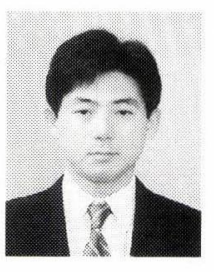

倉林大輔（Daisuke Kurabayashi）

1970 年 9 月 15 日生. 1998 年東京大学大学院工学 系研究科精密機械工学専攻博士課程修了. 現在, 理 化学研究所基礎科学特別研究員. マルチエージェン ト・ロボットシステムの協調作業の研究に従事. 精 密工学会, 日本ロボット学会, 日本機械学会, IEEE などの会員. 博士 (工学).

(日本ロボット学会正会員)

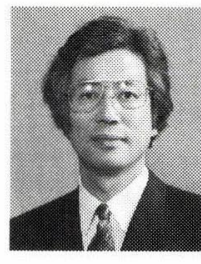

新井民夫（Tamio Arai）

1947 年 8 月 4 日生. 1970 年東京大学工学部精密 機械工学科卒業. 1977 年同博士課程修了。工学博 土. 1987 年東京大学工学部精密機械工学科教授. 1979 年英国エディンバラ大学人工知能学科研究員. 産業用ロボット言語の標準化活動を推進。自動組 立, マニピュレータの協調, 複数移動ロボット, 操 作法などの研究に従事. 精密工学会副会長. IEEE, CIRP などの正 会員.
(日本ロボット学会正会員)

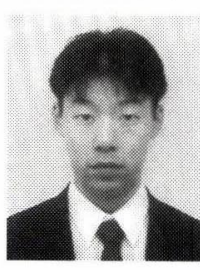

\section{古賀信吾（Shingo Koga）}

1972 年 7 月 1 日生. 1997 年東京大学大学院工学系 研究科精密機械丁学専攻修士課程修了. 現在, 日本 アイ・ビー・エム（株）金融ソリューションサービ ス第一システム部第二開発部にて SI 部門を担当.

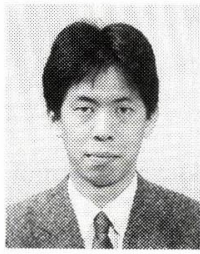

\section{太田 順 (Jun Ota)}

1965 年 2 月 19 日生. 1989 年東京大学大学院工学 系精密機械工学専攻修士課程修了。同年新日本製 鐵 (株) 入社. 1991 年東京大学工学部助手. 同講 師を経て 1996 年東京大学工学系研究科精密機械工 学専攻助教授. 1996 97 年スタンフォード大学客 員研究員. 複数ロボットの計画, 協調制御, ロボッ トのための環境整備の研究に従事. 博士 (工学). 精密工学会, IEEE などの会員. 